\title{
Biobased Materials Production from Biodiesel Residuals of Rapeseed
}

\author{
E. Johansson, ${ }^{1}$ G. M. Spencer, ${ }^{1}$ E. Bettini, ${ }^{2}$ S.-W. Cho, ${ }^{2}$ S. Marttila, ${ }^{3}$ R. Kuktaite, ${ }^{1}$ \\ M. Gällstedt, ${ }^{4}$ and M. S. Hedenqvist ${ }^{2}$
}

\author{
${ }^{1}$ Department of Agrosystems, Swedish University of Agricultural Sciences, P.O. Box 104, 23053 Alnarp, Sweden \\ ${ }^{2}$ Fibre and Polymer Technology, Royal Institute of Technology, 10044 Stockholm, Sweden \\ ${ }^{3}$ Department of Plant Protection Biology, Swedish University of Agricultural Sciences, P.O. Box 102, 23053 Alnarp, Sweden \\ ${ }^{4}$ Innventia, P.O. Box 5604, 11486 Stockholm, Sweden
}

Correspondence should be addressed to E. Johansson, eva.johansson@slu.se

Received 1 February 2012; Accepted 24 February 2012

Academic Editors: X. Colom and H. S. Ku

Copyright () 2012 E. Johansson et al. This is an open access article distributed under the Creative Commons Attribution License, which permits unrestricted use, distribution, and reproduction in any medium, provided the original work is properly cited.

\begin{abstract}
A full biouse of crops for multiple end-uses would contribute to a more economically attractive and thereby more sustainable use of the crop. The purpose of this paper was to evaluate options to develop materials from residuals of rapeseed, originating from the biodiesel (RME) production. Compression molding of rapeseed flour and rapeseed cake residuals was evaluated together with additions of different amount of plasticizer (glycerol), as well as use of various pressing temperatures and times. The results were promising and led to a compact and hard, although somewhat brittle material. The potential to produce materials from the rapeseed residuals from RME production is thus high. Glycerol content was the most important factor increasing tensile strength in the material followed by pressing time. No clear protein polymerization was detected in the produced materials. Thus, despite the promising results, methods to obtain increased protein polymerization should be searched for. Therefore, binding agents, additives, or pretreatment of the rapeseed residuals are needed, or the proteins have to be purified, in order to generate a better polymerization of the proteins.
\end{abstract}

\section{Introduction}

Biodiesel (rapeseed methyl ester (RME)) is today added to conventional diesel to reduce the green-house gas effect (http://www.soiloil.se/, last visited: 2012-04-17). It is produced from the oil of the rapeseed $[1,2]$. The oil is coldpressed from the rapeseed, and the residual is a rapeseed cake. Besides remaining oil, the cake contains crude fibre, carbohydrates, and $33-39 \%$ proteins [3]. The cake is today suitable as animal feed or as a fertilizer. However, if the residual could be used for other purposes, such as for materials and/or chemicals production, these products would give an added value to the fuel production. Thereby, a full biouse of the rapeseed for industrial purposes would contribute to a more economically attractive and thereby more sustainable use of the crop. In line with a growth of a sustainable society, production of sustainable alternatives to petroleum-based plastics is of increasing importance. Plastics produced out of plant proteins have properties, in their plasticized leathery form, similar to for example some types of plasticized PVC (polyvinyl chloride) and thermoplastic elastomers. PVC plastics have until now proven very difficult to replace with more sustainable alternatives. The unique PVC-like properties of plasticized plant proteins originate from the extremely large protein polymers that plant proteins can form [4].

Most essential for determination of the quality of biomaterials are the composition of the proteins in the plant used and the possibilities of these proteins to polymerize [46]. Therefore, suitability of proteins, from different types of crops, has to be evaluated according to their usefulness for production of biomaterials for different end-uses.

Our particular interest was to evaluate possibilities of using residuals from the RME production of rapeseed for production of biobased materials. Such opportunities will give added value to the rapeseed industry, including the RME production, implicating increased sustainability. To our 


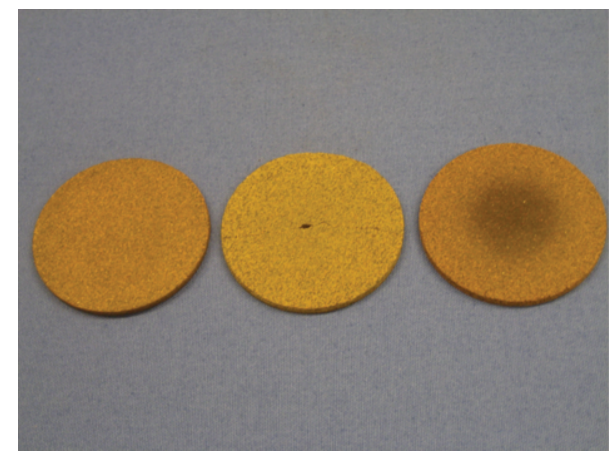

FIGURE 1: Picture of a round-shaped flat compression molded rapeseed material.

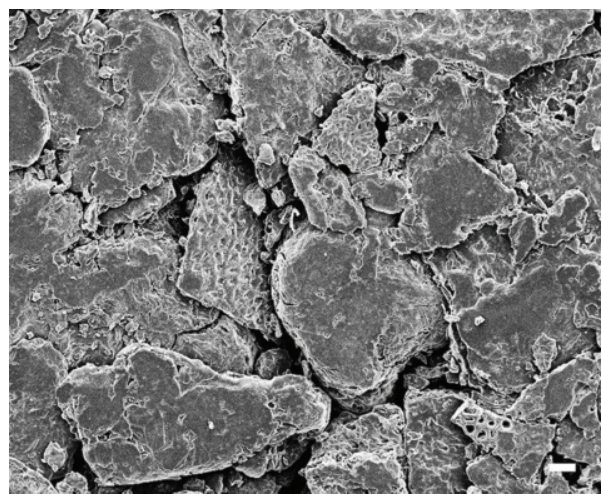

(a)

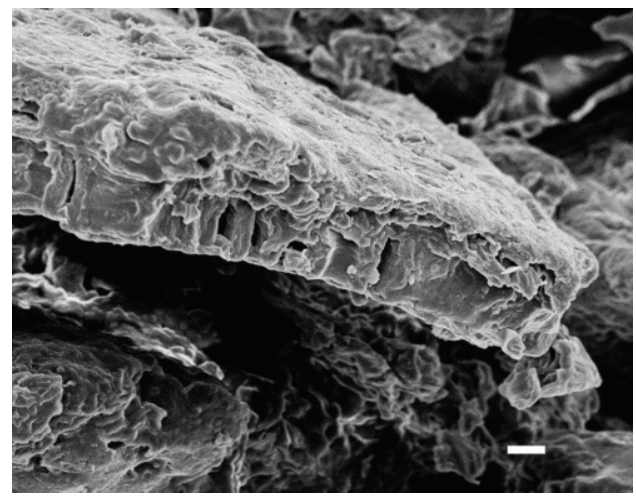

(b)

FIGURE 2: SEM images showing fractured surface of the compression molded rapeseed material: (a) a representative image of the rapeseed material, in this case from rapeseed flour, pressed at $130^{\circ} \mathrm{C}$ at $10 \mathrm{~min}$, without glycerol, scale bar is $30 \mu \mathrm{m}$; (b) image showing residuals of seed coat in the same sample, scale bar is $10 \mu \mathrm{m}$.

knowledge, rapeseed residuals have been evaluated in a one study as regards the use of bio-based materials production [7], although a number of other plant proteins have been tested, gluten, soy, and zein being the most commonly used and the most prosperous ones $[5,6,8,9]$.

\section{Experimental}

Two types of rapeseed residuals, rapeseed flour (RF) obtained from AarhusKarlshamn Sweden AB and rapeseed cake (RC) obtained from Gunnarshogs Jordbruks AB, were evaluated. The samples were compression molded into round (diameter $98 \mathrm{~mm}$ and thickness $4 \mathrm{~mm}$ ) and for the tensile test into dumbbell shaped specimens (narrow width $10 \mathrm{~mm}$, total dumbbell length $140 \mathrm{~mm}$ and thickness $3 \mathrm{~mm}$ ). Samples were pressed with and without glycerol ( $10 \mathrm{wt} \%$ and $20 \mathrm{wt} \%$ based on the total weight) as a plasticizer, at various temperatures $\left(130-180^{\circ} \mathrm{C}\right)$, pressure times $(5-30 \mathrm{~min})$, and pressure (20 MPa, set on the machine gauge). The pressing operation was performed in a Table-Top Press, Polystat 200T (Servitec Maschinenservice GmbH, Germany).

Mechanical properties of the samples were determined in accordance with ISO 527-3 : 1995 using a Zwick Z010 tensile tester equipped with a $500 \mathrm{~N}$ load cell. The testing speed was $10 \mathrm{~mm} / \mathrm{min}$, and an initial grip-to-grip distance of $120 \mathrm{~mm}$ was used. Samples structures were analysed by scanning electron microscopy (SEM) and protein structures analysed by size-exclusion high-performance liquid chromatography (SE-HPLC) as described in Wretfors et al. [10]. For the statistical analyses, SAS software package for Microsoft Windows (SAS Institute Inc, NC, USA) was used. Regression analyses, general linear model (GLM), and analyses of variance (ANOVA) were carried out, followed by calculation of means for the different treatments with determination of significance using LSD (0.05).

\section{Results}

3.1. Appearance and Structure of the Compression Molded Rapeseed Material. When the samples were compression molded into round shapes, they came out as light-to-dark brown specimens with darker spots within (Figure 1). The appearance was rather compact and hard, and somewhat similar to some types of pot-mats. On the other hand, the samples were rather brittle. SEM analysis showed that the material consisted of relatively large particles of uneven size, creating voids between the particles (Figure 2). No obvious differences in the structure were found between differently pretreated samples. The SEM analysis confirmed that the material was heterogeneous, without indications of a 
TABLE 1: Mean values of tensile properties for comparisons of importance of the use of rapeseed type, glycerol content in the samples, press temperature, and press time. In the comparisons all samples are compared differing only in one parameter. That means, for example, that both rapeseed cake and flour and all glycerol contents and pressing times are included when the pressing temperature is evaluated.

\begin{tabular}{|c|c|c|c|}
\hline Source & Maximum stress (MPa) & Strain at maximum stress $(\%)$ & Young's modulus (MPa) \\
\hline \multicolumn{4}{|c|}{ Rapeseed type } \\
\hline Cake & $1.55 \mathrm{a}$ & $0.67 \mathrm{a}$ & $758.4 \mathrm{a}$ \\
\hline Flour & $1.31 \mathrm{a}$ & $0.64 \mathrm{a}$ & $801.4 \mathrm{a}$ \\
\hline \multicolumn{4}{|c|}{ Glycerol content } \\
\hline $0 \%$ & $1.93 \mathrm{a}$ & $0.22 \mathrm{c}$ & $1398 \mathrm{a}$ \\
\hline $10 \%$ & $1.43 \mathrm{~b}$ & $0.60 \mathrm{~b}$ & $598.5 b$ \\
\hline $20 \%$ & $0.86 \mathrm{c}$ & $1.12 \mathrm{a}$ & $230.0 \mathrm{c}$ \\
\hline \multicolumn{4}{|c|}{ Pressing temperature } \\
\hline $140^{\circ} \mathrm{C}$ & $1.28 \mathrm{~b}$ & $0.63 \mathrm{a}$ & $713.9 \mathrm{~b}$ \\
\hline $160^{\circ} \mathrm{C}$ & $1.46 \mathrm{ab}$ & $0.63 \mathrm{a}$ & $782.8 \mathrm{~b}$ \\
\hline $180^{\circ} \mathrm{C}$ & $1.73 \mathrm{a}$ & $0.75 a$ & $925.0 \mathrm{a}$ \\
\hline \multicolumn{4}{|c|}{ Pressing time } \\
\hline $5 \mathrm{~min}$ & $1.36 \mathrm{a}$ & $0.69 \mathrm{a}$ & $675.3 b$ \\
\hline $10 \mathrm{~min}$ & $1.51 \mathrm{a}$ & $0.64 \mathrm{a}$ & $845.3 a$ \\
\hline $20 \mathrm{~min}$ & $1.38 \mathrm{a}$ & $0.67 \mathrm{a}$ & $809.2 \mathrm{a}$ \\
\hline $30 \mathrm{~min}$ & $1.53 \mathrm{a}$ & $0.59 \mathrm{a}$ & $832.0 \mathrm{a}$ \\
\hline
\end{tabular}

Means with the same letters within a column and under the same subheading do not differ significantly (Duncan's Multiple Range Test 0.05 ).

polymer network (Figure 2(a)). Residual seed coat structures could be easily identified in the material (Figure 2(b)). Speckled colour variation of the samples was most likely due to seed coat residuals (Figure 1).

3.2. Tensile Properties of the Material. Generally, the rapeseed residuals resulted in fairly brittle samples. Means of the tensile parameters were $1.45 \mathrm{MPa}$ for maximum stress (ranging from 0.5 to 3.2 ), $0.63 \%$ for strain at break (ranging from 0.15 to 1.52 ), and $782 \mathrm{MPa}$ for Young's modulus (ranging from 110 to $1950 \mathrm{MPa}$ ), for all samples including variation in rapeseed type, glycerol content in the samples, pressing temperature, and pressing time. While comparing influences of the different sources on the tensile properties of the material, glycerol content in the material was found the most important parameter influencing max stress, strain at break, and Young's modulus. Increased glycerol content resulted in a significant decrease in max stress and young's modulus and increased strain at break (Table 1). The second most important parameter for the tensile properties was pressing temperature. Increased pressing temperature led, generally, to increased maximum stress and Young's modulus (Table 1). However, an obvious risk for brittleness was observed with the highest temperature, especially in combination with long pressing time and high glycerol contents, at which treatment of the material was totally degraded so that it was not possible to tensile test at all. This happened with all samples pressed at $180^{\circ} \mathrm{C}$ for $30 \mathrm{~min}$ and for all samples with glycerol pressed at $180^{\circ} \mathrm{C}$. Influence of decreased pressing time was only seen as a decrease in Young's modulus at the pressing time of 5 minutes; otherwise no influence of the pressing time was observed (Table 1). The choice of rapeseed material (rapeseed cake or rapeseed flour) did not influence the tensile properties of the material (Table 1).

3.3. Protein Structures of the Material. Proteins were extracted in three steps and thereafter analyzed by SE-HPLC to evaluate the size distribution of the proteins in the materials. The total amount of proteins extracted in the three extractions for rapeseed flour was used as a standard and set to 100, and thereafter all other amounts of proteins compared were related to this standard amount.

Generally, the first extraction step was the most efficient in amount of proteins extracted (around $60-70 \%$ in all samples). Thereafter, around $15-20 \%$ of the proteins were extracted in the second extraction step, and finally 5$10 \%$ of the proteins were extracted in the third extraction step (Table 2). A relatively higher amount of proteins was commonly extracted in step three from those samples with a relatively low total amount of proteins extracted (Table 2 ).

Independent of rapeseed type, pressing temperature, and pressing time, the samples were supposed to consist of similar amount of total protein. Thus, in those samples with a low total amount of proteins, most likely all proteins have not been extracted with the extraction methods used. This means that the use of rapeseed cake instead of rapeseed flour, decreased pressing temperature, and pressing time reduced the total extractability of the proteins from the samples (Table 2). This reduction in extractability was mainly present in extraction step one although it was also seen in extraction step two (Table 2). Glycerol content in the samples also reduced the total amount of proteins that were extractable from the samples. This can partly be explained by the fact that the content of proteins is lower in the samples containing 
TABLE 2: Mean values of relative amount of proteins extracted for comparisons of importance of the use of rapeseed type, glycerol content in the samples, pressing temperature, and pressing time. Mean value for total extraction of proteins from rapeseed flour is set to 100 , and the rest of the values are related to this set standard value. Vales are relative means of areas under chromatograms from different extractions or from different parts of the chromatograms as a sum after the three extractions. In the comparisons all samples are compared differing only in one parameter. That means, for example, that both rapeseed cake and flour and all glycerol contents and pressing times are included when the pressing temperature is evaluated.

\begin{tabular}{|c|c|c|c|c|c|c|c|}
\hline \multirow{2}{*}{ Source } & \multicolumn{3}{|c|}{ Extraction } & \multicolumn{3}{|c|}{ Chromatogram part } & \multirow{2}{*}{ Total } \\
\hline & 1 & 2 & 3 & 1 & 2 & 3 & \\
\hline \multicolumn{8}{|c|}{ Rapeseed type } \\
\hline Cake & $71.0 \mathrm{~b}$ & $15.1 \mathrm{~b}$ & $4.80 \mathrm{a}$ & $4.69 \mathrm{a}$ & $77.7 \mathrm{~b}$ & $8.27 \mathrm{a}$ & $90.7 b$ \\
\hline Flour & $74.3 \mathrm{a}$ & $20.7 \mathrm{a}$ & $5.08 \mathrm{a}$ & $3.30 \mathrm{~b}$ & $88.3 \mathrm{a}$ & $8.27 \mathrm{a}$ & $100.0 \mathrm{a}$ \\
\hline \multicolumn{8}{|c|}{ Glycerol content } \\
\hline $0 \%$ & $76.0 \mathrm{a}$ & $17.6 \mathrm{a}$ & $4.64 \mathrm{~b}$ & $4.30 \mathrm{a}$ & $84.9 \mathrm{a}$ & $8.94 a$ & $98.2 \mathrm{a}$ \\
\hline $10 \%$ & $69.8 \mathrm{~b}$ & $18.2 \mathrm{a}$ & $5.20 \mathrm{a}$ & $3.69 \mathrm{a}$ & $81.6 \mathrm{~b}$ & $7.71 \mathrm{~b}$ & $93.0 \mathrm{~b}$ \\
\hline \multicolumn{8}{|c|}{ Pressing temperature } \\
\hline $130^{\circ} \mathrm{C}$ & $42.6 \mathrm{~d}$ & $7.71 \mathrm{c}$ & $4.97 \mathrm{~b}$ & $8.04 \mathrm{a}$ & $38.7 \mathrm{~d}$ & $8.55 \mathrm{a}$ & $55.3 \mathrm{~d}$ \\
\hline $145^{\circ} \mathrm{C}$ & $50.3 \mathrm{c}$ & $17.3 \mathrm{a}$ & $6.59 \mathrm{a}$ & $4.41 \mathrm{~b}$ & $63.7 \mathrm{c}$ & $6.31 \mathrm{c}$ & $74.1 \mathrm{c}$ \\
\hline $160^{\circ} \mathrm{C}$ & $79.3 \mathrm{a}$ & $19.9 \mathrm{a}$ & $4.58 \mathrm{~b}$ & $3.46 \mathrm{~b}$ & $92.8 \mathrm{a}$ & $8.60 \mathrm{a}$ & $104.0 \mathrm{a}$ \\
\hline $180^{\circ} \mathrm{C}$ & $67.0 \mathrm{~b}$ & $12.7 \mathrm{~b}$ & $6.09 \mathrm{a}$ & $3.85 \mathrm{~b}$ & $74.3 \mathrm{~b}$ & $7.54 \mathrm{~b}$ & $85.7 \mathrm{~b}$ \\
\hline \multicolumn{8}{|c|}{ Pressing time } \\
\hline $5 \mathrm{~min}$ & $67.0 \mathrm{c}$ & $12.7 \mathrm{c}$ & $6.09 \mathrm{a}$ & $3.85 \mathrm{ab}$ & $74.3 \mathrm{c}$ & $7.54 \mathrm{c}$ & $85.7 \mathrm{c}$ \\
\hline $10 \mathrm{~min}$ & $51.4 \mathrm{~d}$ & $15.0 \mathrm{c}$ & $4.92 \mathrm{~b}$ & $4.53 \mathrm{ab}$ & $59.2 \mathrm{~d}$ & $7.32 \mathrm{c}$ & $71.2 \mathrm{~d}$ \\
\hline $20 \min$ & $75.4 \mathrm{~b}$ & $19.4 \mathrm{~b}$ & $4.19 \mathrm{~b}$ & $3.07 \mathrm{~b}$ & $87.2 \mathrm{~b}$ & $8.66 \mathrm{~b}$ & $98.9 b$ \\
\hline $30 \mathrm{~min}$ & $111.7 \mathrm{a}$ & $23.1 \mathrm{a}$ & $6.03 a$ & $4.80 \mathrm{a}$ & $126.3 \mathrm{a}$ & $9.83 a$ & $140.9 \mathrm{a}$ \\
\hline
\end{tabular}

Means with the same letters within a column and under the same subheading do not differ significantly (Duncan's Multiple Range Test 0.05 ).

glycerol. If the values of extractability were instead compared to the amount of rapeseed cake/flour, a higher amount of proteins extracted was found in the samples with glycerol (results not shown).

The chromatograms were initially divided into 8 fractions (see Figure 3), containing decreasing protein sizes with increasing fraction number. After preliminary analyses, fractions $1-3$ and fractions $4-7$ were found to vary similarly, and these fractions were therefore merged, resulting in fractions $1-3=$ Part 1 with the largest proteins, fractions 4 $7=$ Part 2 with the medium sized proteins, and fraction $8=$ Part 3 with the smallest proteins. Differences in the size of the extractable proteins were observed for different samples. For example, rapeseed cake showed a higher proportion of larger proteins (Part 1) as compared to rapeseed flour, that instead showed a relatively higher proportion of smaller proteins (Part 2, Table 2). Addition of glycerol to the samples reduced the relative part of small proteins (Part 2 and 3 ) as compared to when no glycerol was added to the samples (Table 2). The increase of pressing temperature led to an increase in relatively small proteins (Part 2), similarly as did the increase in pressing time (Parts 2 and 3, Table 2).

3.4. Relationships between Protein Structures and Tensile Properties of the Material. Pearson correlation coefficients showed a significant relationship among some of the tensile parameters of the materials and protein parameters analyzed by SE-HPLC (Table 3). This was especially applicable for Young's modulus that correlated significantly positively

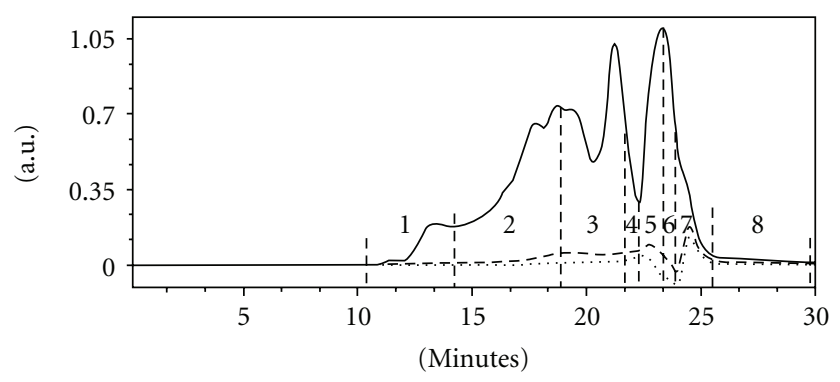

FIgURE 3: A representative picture of a chromatogram (from rapeseed flour, pressed at $140^{\circ} \mathrm{C}$ in $10 \mathrm{~min}$ ) obtained after the three-step extraction of the proteins followed by SE-HPLC analyses. Proteins detected after the first extraction (---), the second extraction(--), and the third extraction (…) are shown as the highest, middle, and lowest chromatograph line in the graph, respectively. Chromatograms were first divided into eight parts as shown in the figure by the numbers $1-8$ below the chromatograms. After preliminary analyses of the results, the parts 1-3 were joined to form Part 1; the parts $4-7$ were joined to form Part 2 and part 8 formed Part 3.

with the relative amount of proteins extracted in the first extraction step as well as with the total protein extracted (Table 3). Further, the relative amount of small proteins (Parts 2 and 3 summed from all three extractions) correlated significantly positively with Young's modulus (Table 3 ). Strain at maximum stress correlated significantly negatively at the $10 \%$ level with the same protein parameters (results not shown). 
TABle 3: Pearson correlation coefficients among different protein extractions and part of the chromatograms and tensile property parameters.

\begin{tabular}{lccc}
\hline Source & $\begin{array}{c}\text { Maximum } \\
\text { stress } \\
(\mathrm{MPa})\end{array}$ & $\begin{array}{c}\text { Strain at } \\
\text { maximum } \\
\text { stress }(\%)\end{array}$ & $\begin{array}{c}\text { Young's } \\
\text { modulus } \\
(\mathrm{MPa})\end{array}$ \\
\hline Extractions & 0.12 & -0.43 & $0.48^{*}$ \\
1 & -0.07 & -0.32 & 0.36 \\
2 & 0.10 & -0.24 & 0.41 \\
3 & & & \\
Chromatogram parts & 0.01 & -0.17 & 0.37 \\
1 & 0.10 & -0.43 & $0.46^{*}$ \\
2 & 0.18 & -0.43 & $0.46^{*}$ \\
3 & 0.08 & -0.39 & $0.46^{*}$ \\
Tot protein extractability & & &
\end{tabular}

* significant at $P<0.05$.

\section{Discussion}

The results from the present investigation show the potentials of producing bio-based materials from rapeseed residuals from the biodiesel industry. Until now, the oil crop residuals from the biodiesel industry have been mainly used as feed [1]. However, the residuals may, beside proteins, also contain antinutritional compounds such as glucosinolates or phytic acids, making them unsuitable to be used as feed. In such cases, the residuals may be used as fertilizers [1], although added value products such as bio-based materials would contribute to a higher profit for the grower/farmer and a better bioeconomy. To our knowledge, only one study has been previously published reporting about opportunities of producing materials from rapeseed cake [7]. Also that investigation reported potentials of using rapeseed for materials production, although a different production method, injection molding, was used, as compared to the compression molding in the present study.

A number of crop residuals and/or protein-rich press cakes or fractions from different types of crops have been evaluated for their potential use in materials production. The most well known of those, being evaluated in a number of studies, is the wheat gluten, a residue from the starch/bioethanol industry and the protein-rich part from wheat after the starch and other carbohydrates have been washed away $[11,12]$. Gluten residue from the bioethanol industry has a high protein content (around 78\%) and is possible to both compression mold and injection mold into materials of relatively high quality in terms of strength and barrier properties $[5,13,14]$. Examples of other plant proteins that have been reported to have potentials for materials production are soy and corn proteins $[8,15,16]$. Of the two latter protein sources, soy proteins have been shown potential for production of base materials even stronger than those built on gluten $[8,10]$. The press cake of oil plants has only been evaluated for material production in a few studies, showing that the rapeseed cake and sunflower cake may be of potential interest for production of composite materials $[7,17,18]$. The use of press cakes or flours that also contain other substances than just proteins may thus have the potential to be used directly as composite materials instead of having to add fibres, thereby risking that the protein matrix and the fibres do not bind properly to each other [19]. A number of studies have reported attempts to develop natural biocomposite materials using different types of protein matrices together with various types of biofibres without great successes $[8,20]$.

The bio-based materials produced from rapeseed residuals, in the present study, were generally very brittle. The structural analysis showed a porous material consisting of hardly fused particles of different sizes. Compared to previously produced bio-based materials, the Young's modulus was higher for the rapeseed materials in the present study (110-1950 MPa) as compared to, for example, gluten-based plastic composite sheets (mean value $86.6 \mathrm{MPa}$ ) produced in, for example, Wretfors et al.'s study [10]. It should be remembered, though, that the gluten material in Wretfors et al.'s study [10] had neither the same shape, nor the same thickness, making the Young's modulus values difficult to compare. Both maximum stress and strain at maximum stress are considerably lower in the rapeseed material as compared to the gluten material (1.43 and 0.65 compared to 3.55 and 2.82 , resp.). Thus, modifications and/or the use of additives are needed in order to be able to use rapeseed residuals for bio-based materials production. In the previous study, in which rapeseed cake was injection molded, different pretreatments were evaluated such as pulverization, hydrothermal, and alkaline treatment as well as the addition of a binding agent. The latter was found necessary in order to be able to injection mold the material [7]. From the different treatments evaluated in the present study, glycerol addition seemed to be the most important for changing the tensile properties of the material, followed by the pressing temperature. Addition of glycerol has been found to increase protein polymerisation in gluten foam materials [21].

Polymerization of the proteins is the one main important factor if proteins are going to be used for bio-based materials production. Protein polymerization properties have, in several studies, been shown to be the main determinant of tensile properties of gluten materials $[5,13]$. The present study gave very little evidence of any higher degree of polymerization of the rapeseed proteins in the rapeseed residuals used. A lower extractability of the proteins was found with lower pressing temperature and pressing time. Tensile data showed the opposite relationship (increased temperature and time led to higher tensile strength), if any. Addition of glycerol influenced tensile properties although no indication of a higher degree of polymerization of the proteins was found in the HPLC data. The reason that the proteins did not polymerize might be due to the type of proteins present in rapeseed, which are mainly globulins [22]. This type of proteins does not naturally form large polymers [23]. Another reason might be the low amount of protein in the rapeseed residuals. Thus, to improve properties of materials obtained from rapeseed residuals, either binding agents, additives, or pretreatment of the rapeseed residuals are needed. Another option might be to purify the proteins 
and use the residuals from the protein purification in other applications, for example, in a biorefinery concept.

\section{Conclusions}

Compression molding of rapeseed residuals allowed to produce potentially interesting specimens of bio-based materials. However, the proteins within the material were not found polymerizing in enough proportion leading to a rather brittle material. In order to produce bio-based materials of commercial interest from rapeseed residuals, the need to polymerize the proteins within the material to a higher degree is crucial. Thus, suitable additives, binding agents, and/or pretreatments of the rapeseed residuals have to be sorted out. Another option is to purify the rapeseed proteins and use the residuals of this protein purification in, for example, within a biorefinery concept.

\section{Acknowledgments}

This work was financed by Formas, Sweden, Project no. 2006-621. The authors thank Maria Luisa Prieto-Linde for practical help in the laboratory and Kerstin Brismar for her assistance with SEM.

\section{References}

[1] Y. Yoshie-Stark, Y. Wada, M. Schott, and A. Wäsche, "Functional and bioactive properties of rapeseed protein concentrates and sensory analysis of food application with rapeseed protein concentrates," LWT-Food Science and Technology, vol. 39, no. 5, pp. 503-512, 2006.

[2] Y. Yoshie-Stark, Y. Wada, and A. Wäsche, "Chemical composition, functional properties, and bioactivities of rapeseed protein isolates," Food Chemistry, vol. 107, no. 1, pp. 32-39, 2008.

[3] E. Çulcuoglu, E. Ünay, and F. Karaosmanoglu, "Rapeseed cake as a biomass source," Energy Sources, vol. 24, pp. 329-336, 2002.

[4] M. Gällstedt, A. Mattozzi, E. Johansson, and M. S. Hedenqvist, "Transport and tensile properties of compression-molded wheat gluten films," Biomacromolecules, vol. 5, no. 5, pp. 2020 2028, 2004.

[5] N. H. Ullsten, S. W. Cho, G. Spencer, M. Gällstedt, E. Johansson, and M. S. Hedenqvist, "Properties of extruded vital wheat gluten sheets with sodium hydroxide and salicylic acid," Biomacromolecules, vol. 10, no. 3, pp. 479-488, 2009.

[6] T. O. J. Blomfeldt, R. T. Olsson, M. Menon, D. Plackett, E. Johansson, and M. S. Hedenqvist, "Novel foams based on freeze-dried renewable vital wheat gluten," Macromolecular Materials and Engineering, vol. 295, no. 9, pp. 796-801, 2010.

[7] K. Baganz, H. Lang, and G. Meissner, "Industrial use of oilseed meal: a reasonable injection moulding compound," European Journal of Lipid Science and Technology, vol. 101, no. 8, pp. 306-307, 1999.

[8] W. Liu, M. Misra, P. Askeland, L. T. Drzal, and A. K. Mohanty, "'Green' composites from soy based plastic and pineapple leaf fiber: fabrication and properties evaluation," Polymer, vol. 46, no. 8, pp. 2710-2721, 2005.

[9] J. W. Lawton, "Zein: a history of processing and use," Cereal Chemistry, vol. 79, no. 1, pp. 1-18, 2002.
[10] C. Wretfors, S. W. Cho, R. Kuktaite et al., "Effects of fiber blending and diamines on wheat gluten materials reinforced with hemp fiber," Journal of Materials Science, vol. 45, no. 15, pp. 4196-4205, 2010.

[11] E. Yalçın, O. Sakiyan, G. Sumnu, S. Celik, and H. Koksel, "Functional properties of microwave-treated wheat gluten," European Food Research and Technology, vol. 227, no. 5, pp. 1411-1417, 2008.

[12] A. E. Farrell, R. J. Plevin, B. T. Turner, A. D. Jones, M. O’Hare, and D. M. Kammen, "Ethanol can contribute to energy and environmental goals," Science, vol. 311, no. 5760, pp. 506-508, 2006.

[13] I. Olabarrieta, S. W. Cho, M. Gällstedt, J. R. Sarasua, E. Johansson, and M. S. Hedenqvist, "Aging properties of films of plasticized vital wheat gluten cast from acidic and basic solutions," Biomacromolecules, vol. 7, no. 5, pp. 1657-1664, 2006.

[14] WO 2010/030234 A1, "Protein-based material with improved mechanical and barrier properties," PCT/SE2009/051028, International application published under the patent cooperation treaty.

[15] J. Bai, V. Alleyne, R. D. Hagenmaier, J. P. Mattheis, and E. A. Baldwin, "Formulation of zein coatings for apples (Malus domestica Borkh)," Postharvest Biology and Technology, vol. 28, no. 2, pp. 259-268, 2003.

[16] S. Kokoszka, F. Debeaufort, A. Hambleton, A. Lenart, and A. Voilley, "Protein and glycerol contents affect physico-chemical properties of soy protein isolate-based edible films," Innovative Food Science and Emerging Technologies, vol. 11, no. 3, pp. 503$510,2010$.

[17] C. Geneau-Sbartaï, J. Leyris, F. Silvestre, and L. Rigal, "Sunflower cake as a natural composite: composition and plastic properties," Journal of Agricultural and Food Chemistry, vol. 56, no. 23, pp. 11198-11208, 2008.

[18] A. Rouilly, O. Orliac, F. Silvestre, and L. Rigal, "New natural injection-moldable composite material from sunflower oil cake," Bioresource Technology, vol. 97, no. 4, pp. 553-561, 2006.

[19] C. Wretfors, S. W. Cho, M. S. Hedenqvist, S. Marttila, S. Nimmermark, and E. Johansson, "Use of industrial hemp fibers to reinforce wheat gluten plastics," Journal of Polymers and the Environment, vol. 17, no. 4, pp. 259-266, 2009.

[20] P. Dalmay, A. Smith, T. Chotard, P. Sahay-Turner, V. Gloaguen, and P. Krausz, "Properties of cellulosic fibre reinforced plaster: influence of hemp or flax fibres on the properties of set gypsum," Journal of Materials Science, vol. 45, no. 3, pp. 793803, 2010.

[21] T. O. J. Blomfeldt, R. Kuktaite, B. Azhdar, E. Johansson, and M. S. Hedenqvist, "Mechanical properties and network structure of wheat gluten foams," Biomacromolecules, vol. 12, no. 5, pp. 1707-1715, 2011.

[22] D. J. Murphy, I. Cummins, and A. S. Kang, "Synthesis of the major oil-body membrane protein in developing rapeseed (Brassica napus) embryos. Integration with storage-lipid and storage-protein synthesis and implications for the mechanism of oil-body formation.", Biochemical Journal, vol. 258, no. 1, pp. 285-293, 1989.

[23] J. Rödin and L. Rask, "Characterization of the $12 \mathrm{~S}$ storage protein of Brassica napus (cruciferin): disulfide bonding between subunits," Physiologia Plantarum, vol. 79, no. 3, pp. 421-426, 1990. 

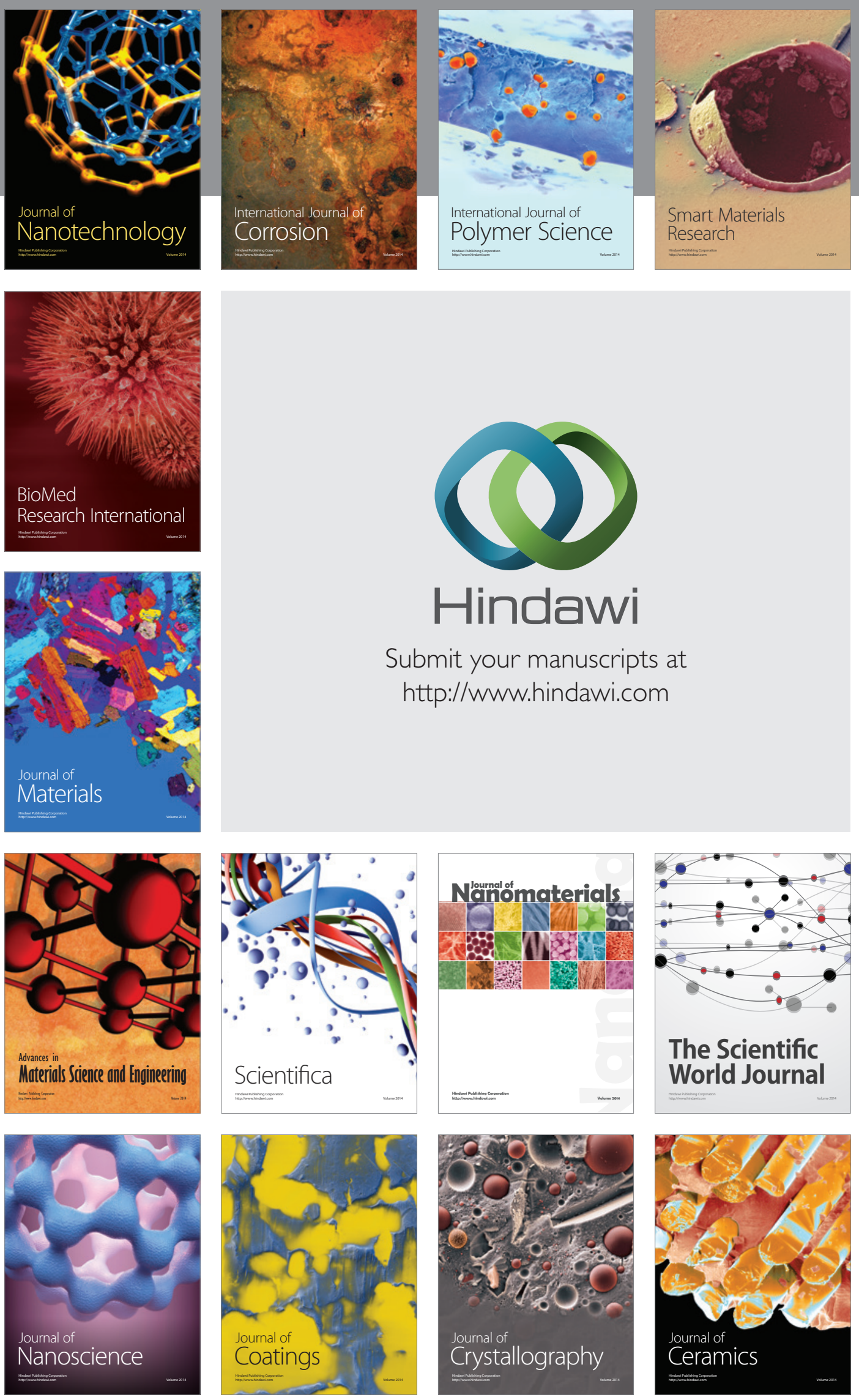

The Scientific World Journal

Submit your manuscripts at

http://www.hindawi.com

\section{World Journal}

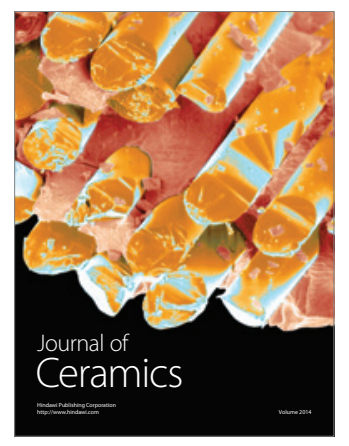

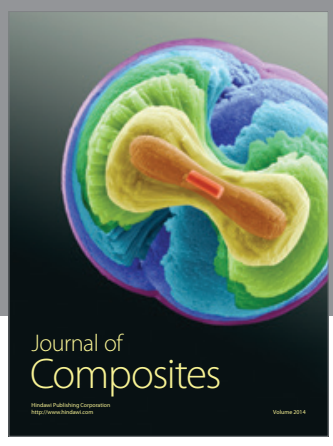
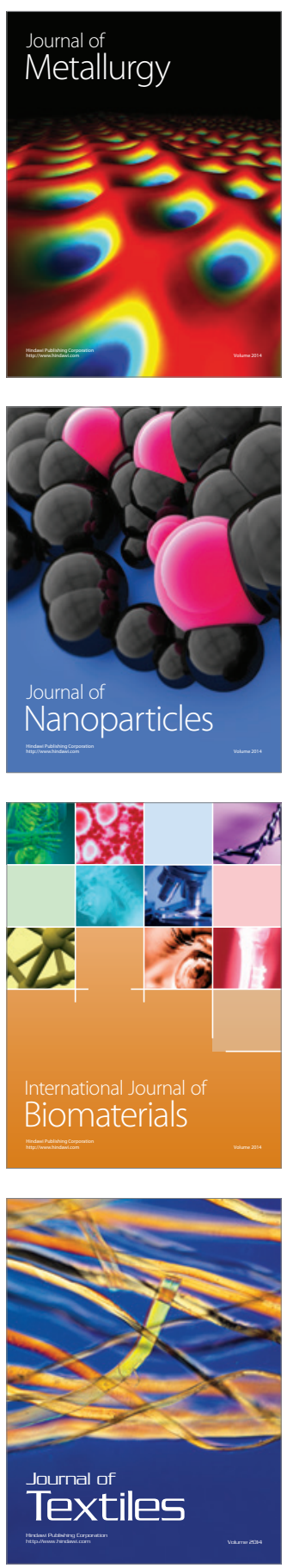